\title{
THE PARAMETERS AFFECT ON POWER COEFFICIENT VERTICAL AXIS WIND TURBINE
}

\author{
A.Y. QASIM ${ }^{1}$, R. USUbAMATOV ${ }^{2}$, Z.M. ZAIN ${ }^{2}$ AND GHULAM ABdUL QUADIR ${ }^{1}$ \\ ${ }^{1}$ School of Mechatronic Engineering, \\ ${ }^{2}$ School of Manufacturing Engineering, \\ University Malaysia Perlis, Pauh Putra, Perlis, Malaysia.
}

ayhk66@yahoo.com,ryspek@unimap.edu.my,zuraidah@unimap.edu.my, gaquadir@unimap.edu.my

\begin{abstract}
This study describes the design of a special type of vertical axis rotor wind turbine with moveable vertically positioned vanes. The novel design increases the torque in the left side of the wind turbine by increasing the drag coefficient. It also reduces the negative torque of the frame which rotates contrary to the wind in the other side. Two different types of models, having different vane shapes (flat vane and cavity shaped vane), were fabricated. Each type consisted of two models with varying number of frames (three and four frames). The models were tested in a wind tunnel with variable wind speed in order to understand the effect of shape, weight, and number of frames on the power coefficient of the wind turbine.
\end{abstract}

ABSTRAK: Di dalam kajian ini, rotor turbin angin berpaksi vertikel sebagai rangka khusus telah direkabentuk dengan lokasi vertikel mudahalih oleh bilah kipas. Rekabentuk ini meningkatkan tork di bahagian kiri turbin angin dengan meningkatkan pekali seretan dan mengurangkan tork negatif rangka yang berputar berlawanan dengan angin pada bahagian lain. Dua jenis model berbentuk berlainan telah difabrikasi (bilah kipas rata dan bilah kipas berbentuk kaviti), dengan setiap jenis mempunyai dua model dengan bilangan rangka yang berlainan (berangka tiga dan berangka empat). Modelmodel telah diuji di dalam terowong angin dengan kelajuan angin yang berbeza bagi mendapatkan kesan rekabentuk, berat dan bilangan rangka ke atas pekali kuasa.

KEYWORDS: design; wind turbine; drag coefficient; vane

\section{INTRODUCTION}

Wind Energy is one of the most cleanly and reliable sources of renewable energy. Nowadays, wind energy generates about one percent of total energy used worldwide. The potential of wind energy is huge and study shows if 20 percent of the possible wind resources are utilized. Most of the wind resources are harnessed by using propeller type wind turbine, which power output efficiency is quite low about 20 percent only due to shape, design, and other factors. Economically, it is quite expensive. World has now come to an era with more inventors creating newer wind turbine with higher efficiency and capability than the current ones.

This paper proposes two types of wind turbines, using vane type vertical axis rotation. This type of wind turbine can increase the output of power with less wind kinetic energy required. New design has simple construction, small size, simple technology, and economical material usage. It forms cavity at one side of turbine while letting the other side of turbine open to let go the wind, hence high drag can occur. This ensures higher efficiency and low starting wind velocity. 
There are various types of wind turbines with different efficiencies. The efficiency is defined as the amount of wind kinetic captured by the wind turbines that can be successfully generated into electrical power.

Our design consists of movable vanes to reduce the negative torque of the frame that rotates contrary to the wind. The wind tunnel is used to measure the power coefficient, torque coefficient and angular velocity as a function of wind velocity. It used different shape, thickness and number of frames (Fig. 1).

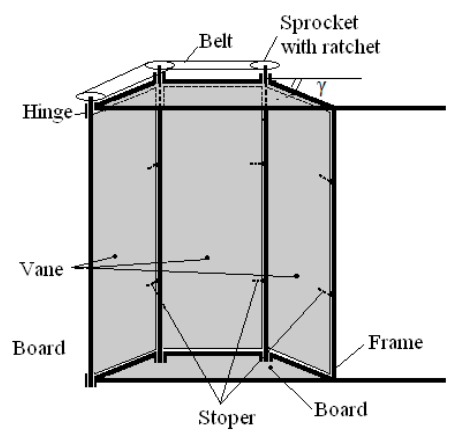

A- Scoop vane

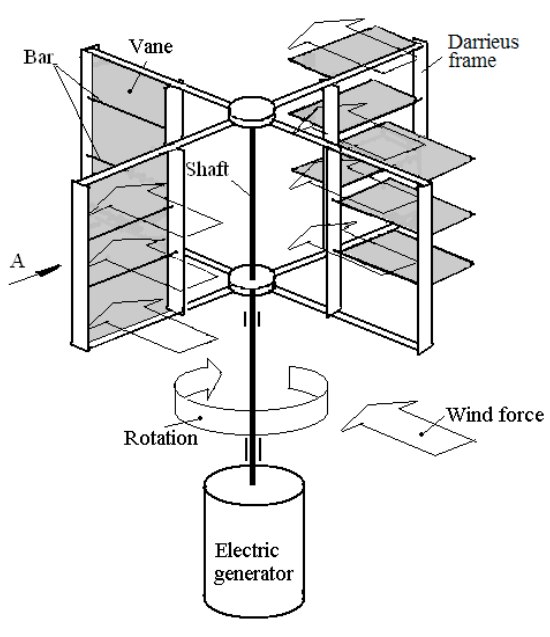

B- Flat vane

Fig. 1 Over view vertical axis wind turbine A) scoop-vane frame B) flat-vane wind turbine.

\section{THEORETICAL ANALYSIS}

The power of the wind is proportional to air density, drag coefficient (the shape of subject), area of the segment of wind being considered, and the natural wind speed. The relationships between the above variables are provided in Eq. 1 below [11].

$$
P_{w}=1 / 2 \rho A V^{3}=T \cdot \omega=1 / 2\left(C_{D} \cdot \rho \cdot A \cdot V^{2} \cdot R\right) \omega
$$

where $\omega$ is the angular velocity, $C_{D}$ is the drag coefficient, $A$ is swept turbine area and $\rho$ is density.

The two models have the same theoretical analysis. To determine the starting torque $T$ on wind turbine vanes, it is necessary to define the whole vane area, and distance from the centre of the output shaft to the centre of wind pressure, then the formula has the following expression,

$$
T=1 / 2\left(A \cdot C_{D} \cdot \rho \cdot V^{2} \cdot R \cdot \sin \alpha\right)
$$

where $R$ is the distance from the shaft centre line to the centre of pressure of the vane surface, other parameters are as specified above.

The output power $(\mathrm{W})$ is calculated by the following equation

$$
\left.W=T \omega=1 / 2 \frac{\left(\rho \cdot A \cdot C_{D} \cdot V^{2} \cdot R \cdot \sin \alpha\right) V}{R} \rho \cdot A \cdot C_{D} \cdot V^{3} \cdot \sin \alpha\right)(W a t t)
$$

Where $\omega$ is the angular velocity of the rotating turbine, $\rho$ is air density, $R$ is impeller turbine radius. 
The torque created by the frames with group of vanes calculated by the following equation:

$$
T=C_{D} p\left[h c\left(b+\frac{c}{2}\right)\right] \sin \alpha
$$

Where $C_{D}$ is drag coefficient, $p$ is wind pressure, and all the parameters are specified in Fig. 2.

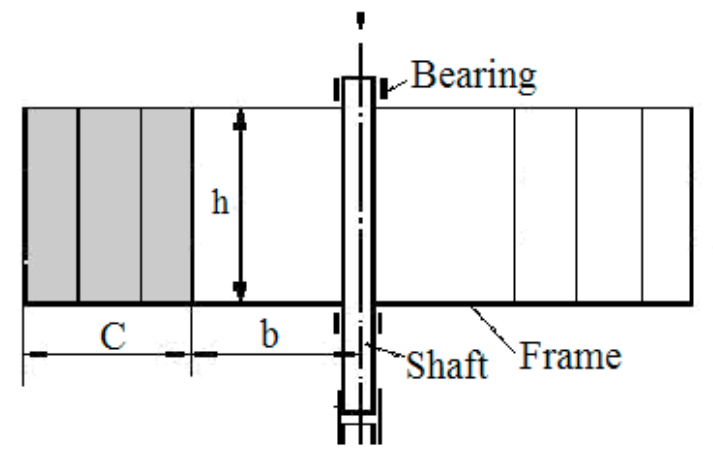

Fig. 2 Rotor dimensions open and closed vanes.

\section{EXPERIMENTAL TESTS IN THE WIND TUNNEL}

\subsection{Drag Coefficient Test}

Cavity shape vane vertical axis wind turbine, has been designed based on obtaining higher values of the drag coefficient. The blade of wind turbine tested used the three model fabricated by metal with same dimensions, $[b=0.07 \mathrm{~m}, h=0.116 \mathrm{~m}, t=1 \mathrm{~mm}]$. The analyses considered drag force test, and drag force coefficient variation with wind velocity. The typical wind tunnel used stationary turbofan engines that sucked air through a duct equipped with a viewing port and instrumentation where models on the shaft are mounted in order to study. The shaft is connected to a digital scale was used to measure the drag force. The following equation was used to find the drag coefficient:

$$
C_{D}=\frac{F_{D}}{0.5 \rho A V^{2}}=\frac{F_{D}}{A \Delta P}
$$

Results obtained by tests as depicted in Fig. 3, show that the frame with cavity shape vane has higher drag coefficients than the flat vane frame.

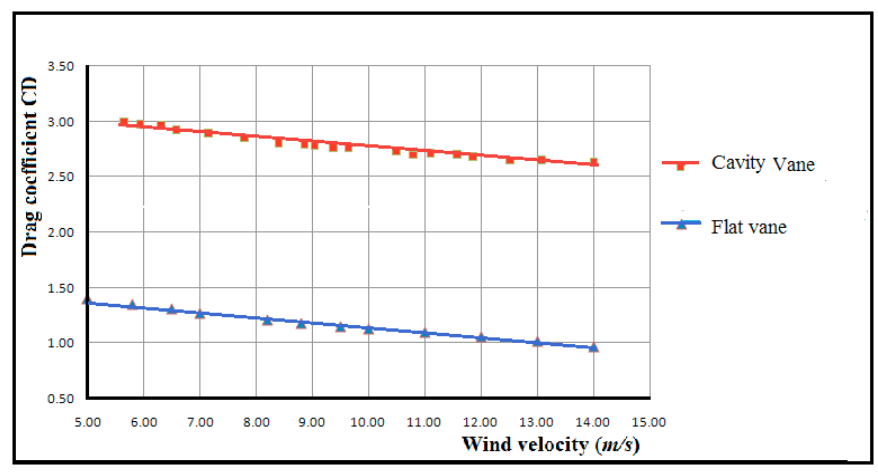

Fig. 3 Drag coefficient for different vanes angle in frame versus wind speed. 


\subsection{Various Frame Tests}

The object of the wind turbine test is to verif the ability of performance design, to get real data, compare with theoretical results and analysis efficiency of product testing. The wind turbine testing used four models, two model of scoop-vane fabricated by hard plastic with same dimensions presented in Fig. 1A, $[c=0.03 \mathrm{~m}, h=0.115 \mathrm{~m}$ and $b=$ $0.07 \mathrm{~m}$, with thickness $t=2 \mathrm{~mm}$ ] and weight is different, [for 3 frame, impeller weight $=172$ gram] and [for 4 frame impeller weight $=236$ gram] .

The two model for flat vane fabricated by metal with dimensions presented in Fig. 1B, [for 4 frame $c=0.048 \mathrm{~m}, h=0.06 \mathrm{~m}$ and $b=0.052 \mathrm{~m}$ ], and [for 3 frame $c=$ $0.044 \mathrm{~m}, h=0.07 \mathrm{~m}$ and $b=0.066 \mathrm{~m}$ ]. The analyses considered power output test, and number of revolutions per min (RPM) of the rotating shaft. The typical wind tunnel used stationary turbofan engines that sucked air through a duct equipped with a viewing port and instrumentation where models on the ball bearings shaft are mounted in order to study. The testing area of the wind tunnel length is the cube with dimensions $300 \times$ $300 \times 300 \mathrm{~mm}^{3}$. The model of the vane-type wind turbine is located in the middle of the wind tunnel testing area and connected with generator. The range of the wind speed used is between $5 \mathrm{~m} / \mathrm{s}$ and $18 \mathrm{~m} / \mathrm{s}$. The wind speed measure by recorded pressure drop from a pittot tube $(\Delta p)$ and use Bernoulli equation to get wind velocity. The tachometer model Compact Instrument Advent Tachopole was used to measure the rotation speed of the wind turbine shaft with the piece of white paper attached, which reflects light.

\subsubsection{Flat Vane Test}

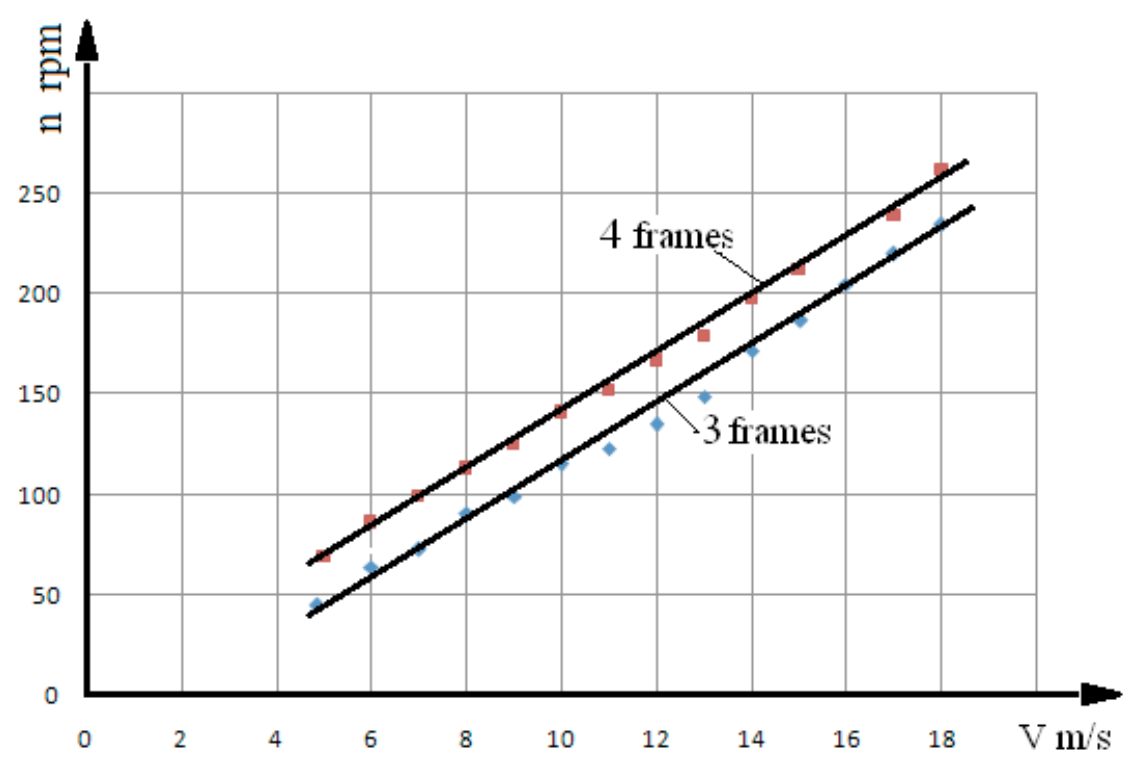

Fig. 4 Number of revolutions of the wind turbine shaft versus the wind speed.

The experiments show that four frames have a higher angular velocity compared to three frames (Fig. 4).

Results obtained in Fig. 5 show that the power coefficient for 3 frame and 4 frame wind turbine with wind speed, we can see that maximum power coefficient for 3 frame is $(0.18)$ at wind speed of $9 \mathrm{~m} / \mathrm{s}$, and the maximum power coefficient for 4 frame is $(0.21)$ at wind speed of $9 \mathrm{~m} / \mathrm{s}$. 


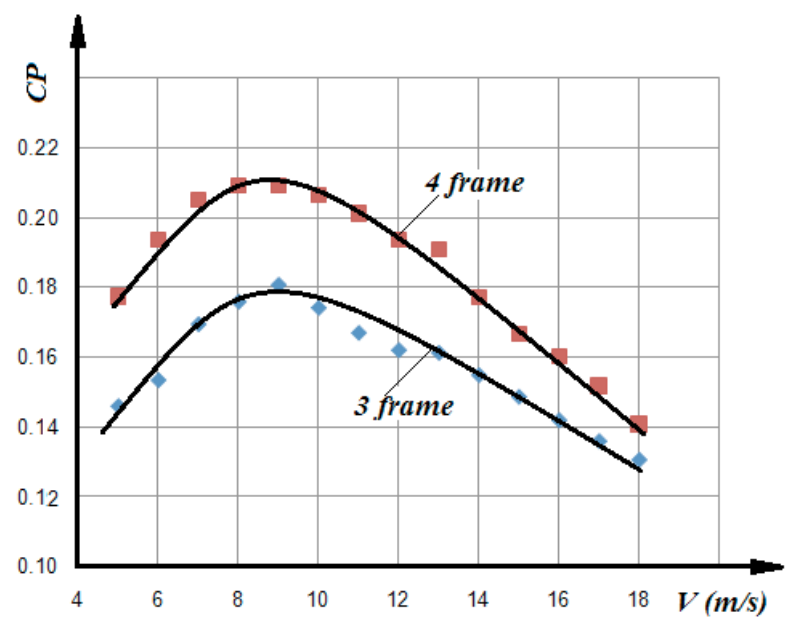

Fig. 5 Power coefficient various wind velocity for 3 and 4 frames flat vanes wind turbine.

\subsubsection{Scoop-Vane Test}

Results obtained by tests show that three frames wind turbine has high angular velocity (rpm) than four frames (Fig. 6).

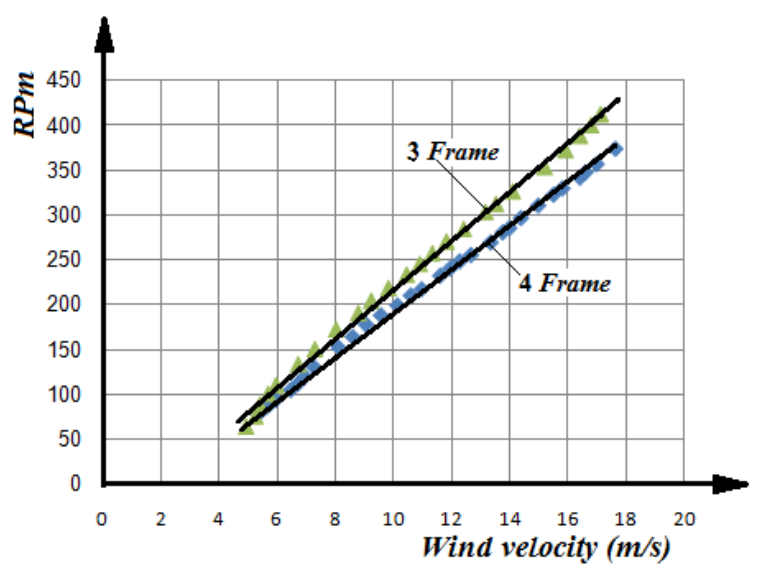

Fig. 6 RPM of 3 and 4 frames Scoop-vane versus wind speed.

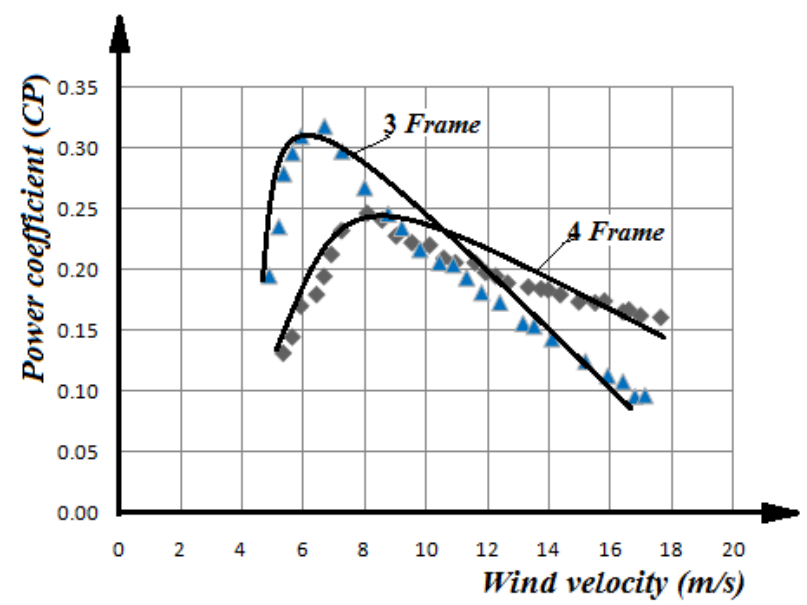

Fig.7 Power coefficient for 3 and 4 frames Scoop-vane versus wind speed. 
Figure 7 shows that three frames turbine model has higher power coefficient than four frames turbine model.

\subsection{Different Thickness Test}

The rotor of wind-turbine model testing used the two models of three frames movable vanes made from the transparent acrylic plates with same dimensions $[c=0.03 \mathrm{~m}$, $h=0.116 \mathrm{~m}$ and $b=0.07 \mathrm{~m}]$ and different thickness of metal $[t=1 \mathrm{~mm}$, impeller weight $=114$ grams, and $t=2 \mathrm{~mm}$, weight $=170$ grams $]$. The analyses considered power output test, and number of revolutions per second of the rotating shaft.

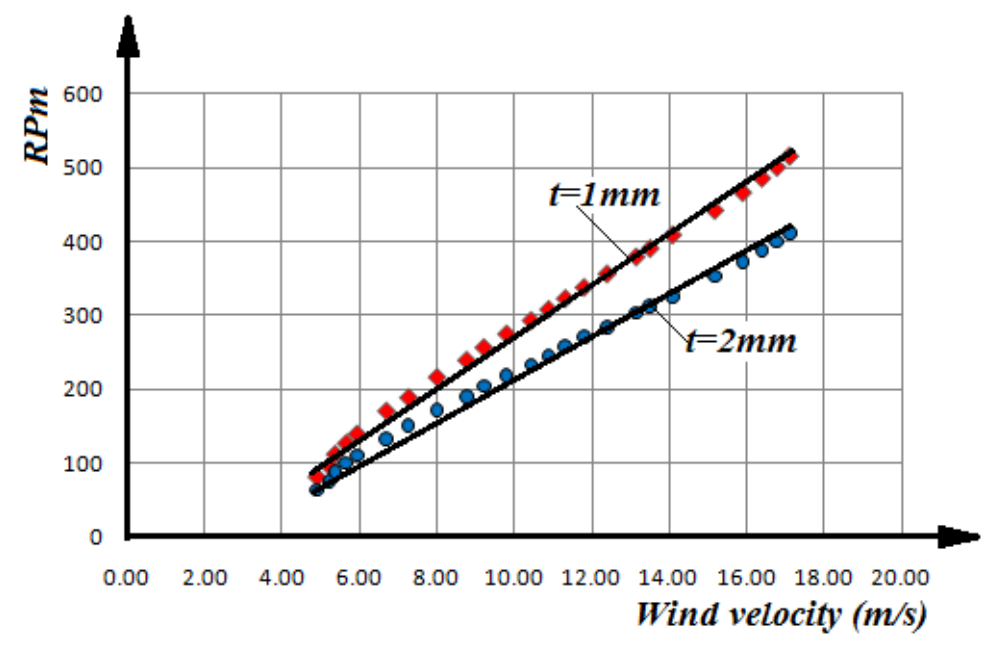

Fig. 8 RPM of three and four frames impeller versus wind speed.

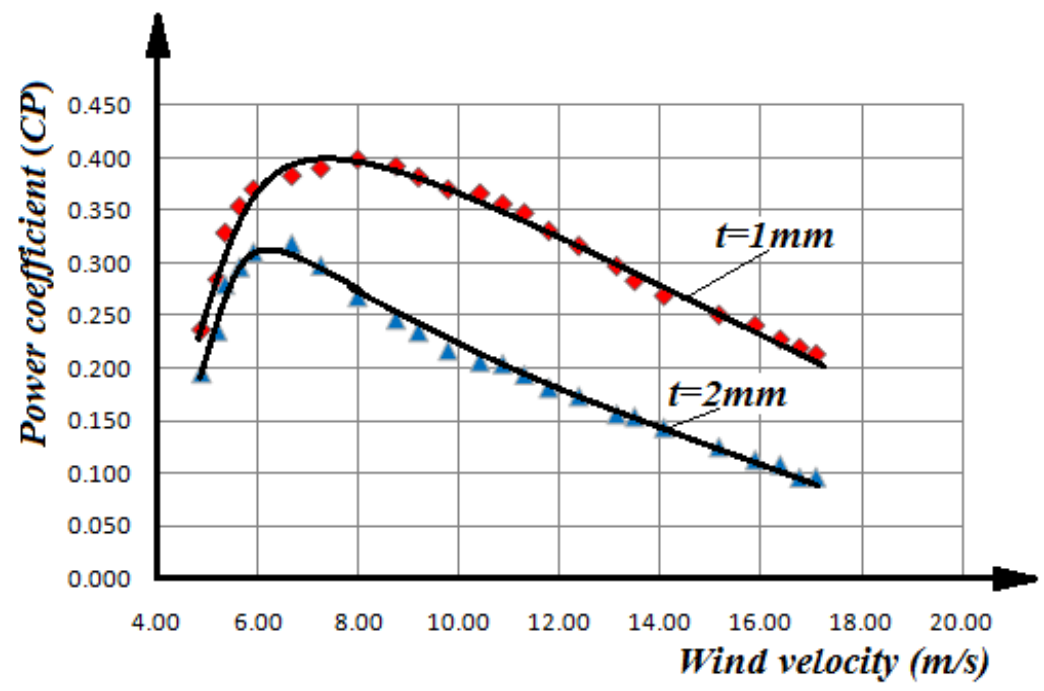

Fig. 9 Power coefficient for three frames different weight versus wind speed.

Results obtained in Fig. 9 show that the power coefficient wind turbine against wind speed, we can see that maximum power coefficient for low weight impeller is (0.4) at wind speed of $7 \mathrm{~m} / \mathrm{s}$, and maximum power coefficient for high weight impeller is $(0.31)$ at wind speed of $6 \mathrm{~m} / \mathrm{s}$. 


\section{CONCLUSION}

The impeller type wind turbine with scoop-vanes has higher efficiency compares with flat vanes. This is caused the wind turbine has the high drag factor enables to capture wind energy. This type wind turbine has good technical properties and can be used for generating a power more efficiently for the low speed of the wind.

Increase drag factor can increase the output power, and the vane type wind turbine can be high efficiency.

In a flat vane rotor, increase number of frame can increase angular velocity of the rotor. The power coefficient is measured experimentally to be equals to 0.18 and 0.21 for three and four frames, respectively.

Figure 3 shows the cavity frame shape increase the drag coefficient to 3, when the drag coefficient for flat vane is 1.3 .

In cavity shape frame increase the number of frame will decrease angular velocity and give a low-power coefficient. The power coefficient is measured experimentally to be equals to 0.31 and 0.24 for three and four frames, respectively. When we used the different thickness for three frames cavity shape the power coefficient is measured to be equals to 0.4 and 0.31 for thickness $1 \mathrm{~mm}$ and $2 \mathrm{~mm}$, respectively.

The possible reasons for getting lower results for the four-frame than the three-frame in the experiment are:

1. Higher weight (four-frame impeller 236 grams vs. the three-frame impeller at 172 grams)

2. Decreasing the distance between two vanes, then the limit has a lower drag force as seen in Fig. 8.

3. When the number of blades is increased to four, the air that strikes the second blade is reflected back onto the following blade, so that the following blade rotates in a negative direction compared to the succeeding blade.

4. The vortex consists and still air area behind the vane gives high resistance, in four frames more than three frames.

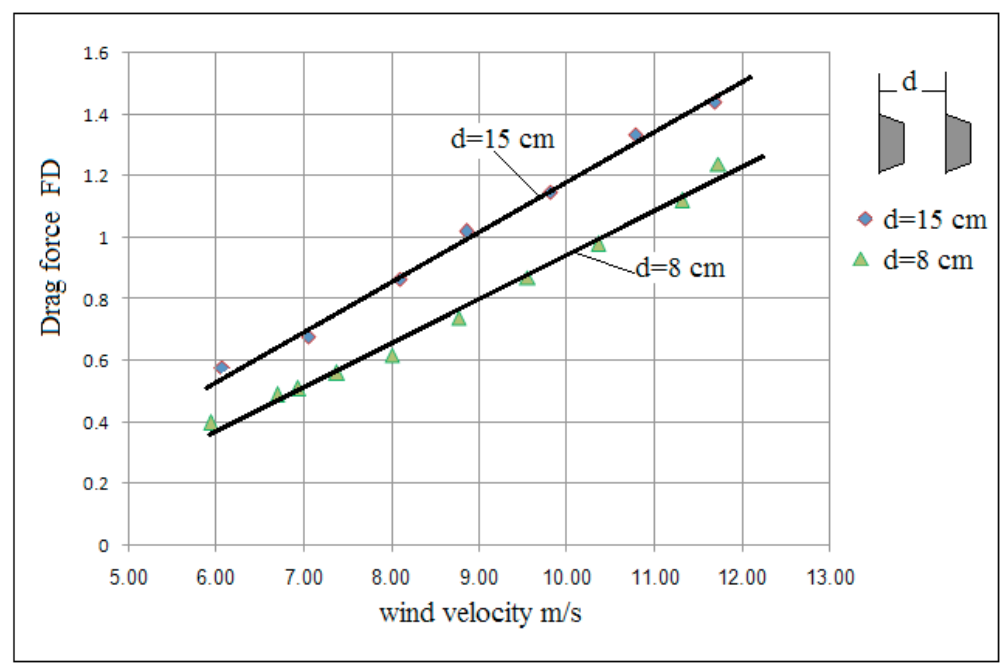

Fig. 8 Drag force versus wind speed in wind tunnel with different distance between the two vanes. 
Weight has significant effect on power coefficient, an increase in the thickness of rotor from $1 \mathrm{~mm}$ to $2 \mathrm{~mm}$ (weight 114 grams to 172 grams) reduces the power coefficient by around $8 \%$ (from $40 \%$ to $32 \%$ ). The new turbine presents a simple construction and can be manufactured from from cheap materials using simple technology.

\section{REFERENCES}

[1] Manwell JF, MC Gowan JG, Rogers AL. "Wind Energy Explained, Theory, Design and Application". . England:Wiley \& Sons, 2002.

[2] Sathyajith, Mathew,Wind Energy Fundaments, Resource Analysis and Economics. Springer 2006;1.

[3] Eggleston, David M., and Forrest Stoddard. "Wind turbine engineering design". Wiley\& Sons, 2004.

[4] Spera David A. "Wind Turbine Technology". New York. ASME Press, 1994;

[5] R. Usubamatov, Z.M.Zain, R. Bhuvenesh, F.Khammas. "New vane type wind turbine of high efficiency, CNGRT88".Proceedings of World Engineering Congress, 2010.

[6] Gasch, Robert, and Jochen Twele, "Windkraftanlagen Grundlagen." Entwurf, Planung und Betrieb, Teubner, Wiesbaden (2007).

[7] Y.A.Cendel Y.A., "ans J. M. Cimbala. Fluid Mechanics, 2006," McGraw Hill.

[8] Usubamatov R., Zain Z. M., Khammas F. A., A. Younus. "Impeller type wind turbine. Published by the Australian Institute of High Energetic Materials (ABN: 68126426 917) 2010." (2010).

[9] Robert Howell, Ning Qin, Jonathan Edwards, Naveed Durrani. "Wind tunnel and numerical study of a small vertical axis wind turbine". Renewable Energy 35.2 (2010) 412-22.

[10] Muller. Gerald, Mark F. Jentsch, Euan Stoddart. Vertical axis resistance type wind turbines for use in buildings. Journal Renewable Energy 34 (2009) 1407-12.

[11] Johnson, Dr. Gary L. (November 21, 2001) "Wind Turbine Power - Ch 4. Wind Turbine Power, Energy and Torque.” (2005). 